Canadian

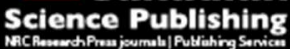

Environmental Reviews Dossiers environnement

\title{
Environmental DNA as a valuable and unique source of information about ecological networks in Arctic terrestrial ecosystems
}

\begin{tabular}{|r|l|}
\hline Journal: & Environmental Reviews \\
\hline Manuscript ID & er-2016-0060.R2 \\
\hline Date Submitted by the Author: & 04-Jan-2017 \\
\hline Complete List of Authors: & $\begin{array}{l}\text { Zielińska, Sylwia; Univeristy of Gdansk, Department of Molecular Genetics } \\
\text { of Bacteria } \\
\text { Kidawa, Dorota; Univeristy of Gdansk, Department of Vertebrate Ecology } \\
\text { and Zoology } \\
\text { Stempniewicz, Lech; Univeristy of Gdansk, Department of Vertebrate } \\
\text { Ecology and Zoology } \\
\text { Łoś, Marcin; Univeristy of Gdansk, Department of Molecular Genetics of } \\
\text { Bacteria } \\
\text { Łoś, Joanna; Univeristy of Gdansk, Department of Molecular Genetics of } \\
\text { Bacteria }\end{array}$ \\
\hline Keyword: & \begin{tabular}{l} 
Arctic, eDNA, metagenomics, environmental samples, faeces and soil \\
\hline
\end{tabular} \\
\hline
\end{tabular}




\section{Environmental DNA as a valuable and unique source of information about ecological}

2 networks in Arctic terrestrial ecosystems

3 Sylwia Zielińska ${ }^{*}$, Dorota Kidawa ${ }^{2}$, Lech Stempniewicz ${ }^{2}$, Marcin Loś $^{1}$ and Joanna M Łoś ${ }^{1}$

$4{ }^{1}$ Department of Molecular Biology, University of Gdansk, Wita Stwosza 59, 80-308, Gdansk,

5 Poland, Present address:Department of Molecular Genetics of Bacteria, University of Gdansk,

6 Wita Stwosza 59, 80-308, Gdansk, Poland

$7 \quad{ }^{2}$ Department of Vertebrate Ecology and Zoology, University of Gdansk, Wita Stwosza 59, 80-

$8 \quad 308$, Gdansk, Poland

9 Correspondence: Sylwia Zielińska, University of Gdansk, Department of Molecular

10 Genetics of Bacteria, Wita Stwosza 59, Gdansk 80-308, Poland, +48585236047 ,

11 sylwia.zielinska@biol.ug.edu.pl

12 Word count: 6329

13 Abstract

14 Arctic terrestrial ecosystems are particularly vulnerable to the effects of ongoing and 15 predicted climate changes. The current states of environmental biodiversity and ecological 16 networks in the Arctic need to be known and understood in order to monitor how they change 17 and how these changes may influence the particular components of the ecosystem. Despite the 18 fact that the Arctic tundra is generally poor in nutrients, it has a surprisingly high biodiversity, 19 especially of invertebrates and microorganisms. Besides macroclimatic features, there may be 20 local factors influencing biodiversity, such as microclimate, water availability or large seabird 21 colonies depositing guano. This last can have a substantial impact on the soil's 22 physicochemical features, and consequently the distribution, number and diversity of tundra23 associated plants and animals in the vicinity of the colony. Changes in the Arctic biodiversity 24 and the functioning of the ecosystem at all trophic levels are difficult to investigate using 25 traditional methods. In this review, we discuss how modern molecular techniques, including 
next generation sequencing, influence our ability to investigate and understand this ecosystem at both the micro- and the macro-scale and how they can complement the more traditional approaches to studying ecological networks in the Arctic.

Key words: Arctic, eDNA, metagenomics, environmental samples, faeces, soil

\section{Introduction}

The Arctic region comprises about $4.8 \%$ of the Earth's land surface north of the tree line, where the average temperature in July, the warmest month, is below $10{ }^{\circ} \mathrm{C}$ (Remmert 1980, Stonehouse 1989, Meltofte 2013). The Arctic comprises heterogeneous habitats created by gradients of geomorphology, latitude, proximity to coasts and oceanic currents. The physical characteristics of the Arctic important for structuring biodiversity include extreme seasonality, short growing seasons with low temperatures, the presence of permafrost, snow and ice cover. The high Arctic is dominated by bare, sparsely vegetated soils with a small number of plant and animal species and a short growing season. The low Arctic area is covered by mainly shrubby tundra vegetation (Remmert 1980, Stonehouse 1989). Species richness is generally low in the Arctic and tends to decline from the low to the high Arctic (ABA 2013, Meltofte 2013).

Short thaw seasons, low soil temperatures and low rates of evapotranspiration during the growing seasons in the Arctic severely constrain microbially mediated processes such as decomposition and nutrient mineralization, thus lowering rates of nutrient supply to plant roots. As a result, rates of plant growth and nutrient cycling between plants and soils are exceedingly low in terrestrial Arctic ecosystems. These are thus considered to be generally simple, with poor species diversity, and characterized by short food chains and a permanent shortage of nutrients. In fact, however, the biodiversity, especially that of cold-resistant species of invertebrates and microorganisms, is surprisingly high (e.g. Coulson 2007, Danks 
and Smith 2009, Chu et al. 2010, Coulson et al. 2014, Koyama et al. 2014, Marusik et al. 2016, Zielińska et al. 2016c). Despite the extreme conditions, even glaciers can be a habitat for various microorganisms (Musilova et al. 2015). In cold environments, both soil and permafrost are dominated mainly by bacterial, archeal and fungal lineages (Makhalanyane et al. 2016).

The unique area of the Arctic is receiving much attention as a consequence of observed and predicted rapid environmental changes associated with global climate change (e.g. AMAP 2012, Gough et al. 2016, Makhalanyane et al. 2016). Although the last 10000 years have been characterized by climatic stability, air and sea surface temperatures have increased markedly during the last few decades, and these changes are the fastest in the Arctic region (Hansen et al. 2010, GISTEMP Team 2016). Temperature, the most important environmental factor, has a strong impact on ecosystem structure and functioning, often contributing to a cascade effect (Cooper 2014). Arctic terrestrial ecosystems are highly sensitive, since even a small increase in temperature causes a decline in glacier ice and snow, and melting of permafrost (Callaghan et al. 1995, AMAP 2012, Gilg et al. 2012, Stempniewicz et al. 2016). Consequently, changes in Arctic biodiversity and the functioning of the ecosystem at all trophic levels, from microorganisms to vertebrates, are being observed and are expected to continue (e.g. ACIA 2007, Stempniewicz et al. 2007, Grémillet et al. 2009, Gilg et al. 2012).

The availability of liquid water is regarded as the most important abiotic stress factor influencing polar terrestrial communities. Precipitation occurs mainly as rain in the maritime zones during summer and inland as snow. However, temperature influences the rate of snowand ice-melt, and eventually, levels of soil moisture, which is essential for the abundance of soil invertebrates and microorganisms. Increases in temperature and precipitation will affect ecosystems in a complex manner: longer growing seasons, thawing permafrost and changes in 
the water cycle are expected to have the greatest impact on terrestrial ecosystems (Convey et al. 2014, Cooper 2014). Despite the fact that severe environmental conditions in the Arctic appear to be impeding the establishment and reproduction of alien species, rising temperatures and an increasing human presence are making it easier for new species, including parasites and other pests, to gain a foothold in the Arctic (Coulson et al. 2014).

Moreover, increases in vegetation productivity and climate feedbacks induced by shrub encroachment are expected to mediate changes in trophic interactions (Croll et al. 2005, Cooper 2014). Since the growing season in the Arctic is very short, even small changes in its duration will have consequences for most resident plants and animals. Plants may experience a direct effect in the form of increased growth, productivity and changes in community structure, which may provide better living conditions for herbivores. Climate change, however, may lead to a phenological mismatch between the timing of reproduction in herbivores, birds and mammals, and the availability of their food (Post and Forchammer 2008, Moe et al. 2009). Non-migratory animals could be severely affected by changed winter snow conditions, the alternating melting of snow and freezing of the tundra surface known as "rain-on-snow events" that negatively affect the availability of plant food to herbivores. Such weather extremes in the Arctic may become more frequent in the future (Kohler and Aanes 2004, Vikhamar-Schuler et al. 2013, Descamps et al. 2016). Overall, the consequences of current warming for Arctic biodiversity may be serious and multifaceted, and hence difficult to predict (ABA 2013, Eamer et.al. 2013). as changes in ecosystems can be monitored faster and more easily using molecular approaches. This is particularly important in the case of polar ecosystems, given the conspicuous climate changes and the roughly three times faster temperature increase than in other regions of the world (ACIA 2007). Because of the extensive research area, harsh 
100 conditions and environmental complexity, the proper identification and monitoring of Arctic

101 biodiversity and ecological networks can be quite problematic. For instance, although faeces

102 residues can indicate the presence of particular animals (Brinkman et al. 2010, Goode 2011),

103 the structure, functioning and health of their populations remains unknown. The ongoing

104 development of molecular tools, metagenomics and environmental DNA (eDNA) techniques

105 means that we can obtain more detailed information about microorganisms, plants and

106 animals based only on easily accessible environmental samples, like soil or faeces. A

107 combination of soil microbiology and metagenomics, together with next generation

108 sequencing (NGS) and eDNA techniques, could be used for a comprehensive analysis of a

109 specific environment (e.g. Cowan et al. 2015, Makhalanyane et al. 2016). These molecular

110 techniques can deliver a large amount of data concerning both micro- and macroorganisms

111 and are useful for considering many ecological aspects of the Arctic ecosystem. Traditional

112 ecological methods based on observation, collecting and trapping, though effective, are much

113 more time-consuming than molecular approaches like metagenomics or eDNA analysis,

114 which are often much easier to carry out and above all more quickly. Molecular techniques

115 may thus be potentially valuable for monitoring the rapid changes taking place in the Arctic

116 ecosystem.

118 Ornithogenic soils - a specific example of the Arctic environmental network

119 In general, the availability of nitrogen in the Arctic is limited because of low 120 temperatures, low precipitation, slow chemical weathering of bedrock and poor soil aeration 121 (Callaghan 1995, Wainwright et al. 1998). Arctic soils are permanently frozen (permafrost) 122 except for a thin surface zone that thaws each summer. Besides environmental determinants 123 like temperature and humidity, additional factors, such as the supply to the local tundra of 124 marigenic nutrients by colonial seabirds and through sea spray can have a substantial impact 
125 on the soil's physicochemical features (Oechel 1997, Zwolicki et al. 2013, 2016). However,

126 such patterns of soil fertilization associated with higher species richness generally occur to

127 only a very limited extent. A specific example is that of colonial seabirds, which forage at sea

128 and breed on land, and deposit large amounts of organic matter (i.e. guano, eggshells,

129 feathers, carcasses) near their colonies, enhancing the formation of ornithogenic soils

130 (Stempniewicz 1990, Zwolicki et al. 2013, 2016). The areas adjoining seabird colonies

131 constitute a rare oasis in Arctic habitats. The large-scale transport of organic and inorganic

132 matter from the sea to the land supports diversification of local Arctic communities. Soil

133 fertilization close to the seabird colonies facilitates the diversity and abundance of terrestrial

134 plant communities and their accompanying fauna (Vidal et al. 2003, Stempniewicz et al.

135 2007, Zwolicki et al. 2013, Wojciechowska et al. 2015). The abundance of invertebrates, such

136 as springtails (Collembola) or water bears (Tardigrada), that inhabit mosses, lichens,

137 liverworts and soil, was found to be higher where soils had become ornithogenically enriched

138 (Stempniewicz et al. 2006, Zawierucha et al. 2015, Zmudczyńska-Skarbek et al. 2015). Also,

139 numbers and biomasses of each microorganism taxon and the whole structure of microbial

140 communities can fluctuate in different soil environments, as a result of the changing

141 physicochemical features of the soil (Aislabie et al. 2009, Grzesiak et al. 2015, Zielińska et al.

142 2016c).

143 Moreover, physicochemical soil parameters that impact the vegetation structure can be

144 directly or indirectly associated with invertebrate and vertebrate diversity. A rich vegetation

145 attracts populations of herbivores, and subsequently predators, scavengers and decomposers

146 (Croll et al. 2005, Jakubas et al. 2008, Zmudczyńska et al. 2012). By their intensive grazing,

147 herbivores make room for a more diverse group of plants in the ecosystem than just lichens

148 (Van der Wal and Brooker 2004). Jakubas et al. (2008) showed that the abundance of

149 herbivores associated with bird colonies depends on the size and location of the latter, which 
150 in turn is correlated with the richness of the area near the bird colony. In addition, the

151 presence of numerous herbivores and top predators in the area can also enhance soil nutrient

152 concentrations (from urine, faeces and prey remnants (Gharajehdaghipour et al. 2016). By

153 converting organic compounds into easily assimilated nutrients, faeces are a source of soluble

154 nitrogen introduced into the environment. Figure 1 illustrates the theoretical ecological

155 network associated with ornithogenic soil, developed on the basis of DNA extracted from soil

156 and faecal samples, and showing the mutual interactions of particular network chains. These

157 mutual relations in the rapidly changing Arctic ecosystem can be monitored relatively quickly

158 and simply using metagenomics or eDNA techniques.

159 How the food web ecology in remote, pristine ecosystems can be affected was 160 exemplified by the introduction of the Arctic fox in the Aleutian archipelago. Croll et al.

161 (2005) showed that the decline in seabird densities caused by the introduction of Arctic foxes

162 could influence the whole island environment. Based on $\delta^{15} \mathrm{~N}$ measurements from soil, plants

163 and animal tissues, they showed that fox-free islands inhabited by large seabird populations

164 were strongly subsidized by marigenic nutrients, which are the flywheel of the whole island

165 ecosystem. Islands where the fox had been introduced, as a result of which the seabird

166 populations became depleted, had a reduced nitrogen input from the sea to the land. Based on

167 that example, it is easy to see how a food web evolves when one link in the chain is modified.

168 In this specific case, introduction of the fox transformed the islands from grasslands to 169 maritime tundra (Croll et al. 2005).

\section{Environmental DNA}

172 The focus on environmental DNA (eDNA) has led to a new approach to monitoring 173 species in different environments. This technique is based on the fact that all animals leave 174 DNA behind. By taking field samples and analysing them for eDNA, it is possible to 
175 demonstrate the presence of a species without observing or capturing individuals (Valentini et

176 al. 2009). Moreover, environmental DNA methods have enormous potential for the non-

177 invasive detection, i.e. the identification, spread and abundance, population size estimates or

178 conservation of highly sensitive target species. Environmental DNA also represents an

179 important source of information on the present and past biodiversity of the flora and fauna

180 (Mächler et al. 2013, Thomsen and Willerslev 2015).

181 The robustness of eDNA analysis has its potential problems, especially in case studies

182 that do not aim to analyse the macrofauna or macroflora present in the environment. Since the

183 analysis of such samples as faeces, plant or animal remains, or live microbial mats provides

184 information that is relatively easy to interpret and is quite up-to-date, the results of deep soil

185 analyses, for example, may be problematic. The reason for this is that the presence of DNA in

186 the environment does not necessarily mean that the organism from which the DNA originated

187 is currently present in this environment. Even in a warm climate, DNA degradation or the

188 decay of the organisms may be not fast enough to yield the latest data about the content of

189 live organisms or microorganisms in the sample (Liu et al. 2015). As the average temperature

190 falls, the process also slows down (Kim and Wuertz 2015); in the Arctic the process may be

191 extremely slow. Permafrost can preserve genetic traces of organisms that have been extinct

192 for millennia. Suffice it to mention that it has been possible to sequence mammoths, which

193 have been extinct for a few thousand years (Palkopoulou et al. 2015). One may anticipate

194 similar problems with other organisms and microorganisms. This always has to be taken into

195 consideration, so the results obtained from DNA analysis should always be treated with the

196 utmost caution. Hence, eDNA analysis cannot be used as a stand-alone method but should

197 always be supplemented by, or supplement, a comprehensive environmental study.

198 Another aspect of eDNA analysis is species identification, especially in the microbial

199 world. Next Generation Sequencing enables thousands of 16S rRNA sequences to be obtained 
200 and analysed relatively easily. These regions are typically sequenced using only a single pass, 201 which can result in at least one sequencing error; in consequence, obtaining $100 \%$ identical 202 sequences, even in such a highly conservative region, will be hard. This prevents us from 203 using the biological meaning of 'species'. This approach requires some degree of sequence 204 divergence $(95 \%, 97 \%$ or $99 \%$ sequence similarity cut offs are typically allowed) and results 205 in clustering into nearly-identical tags, referred to as Operational Taxonomic Units (OTU; 206 clustering sequences based upon similarity) (Morgan and Huttenhower 2012, Nguyen et al. 207 2016). The sequences are stored and can be matched against several databases, such as 208 GreenGenes (DeSantis et al. 2006), the Ribosomal Database Project (Cole et al. 2009) and 209 Silva (Pruesse et al. 2007). It should also be borne in mind that the sequences in some 210 databases are not accurate, neither is there any consensus quantitative definition of genus or 211 species based on 16S rRNA gene sequence data. Consequently, as taxonomic assignments 212 may depend on the reference database used, their results may change accordingly, and 213 significantly so (Hiraoka et al. 2016). At present, identification to lower taxonomic levels, 214 particularly to bacterial species, is seldom possible. The precision of this type of bacterial 215 community member identification will increase over time, as databases are updated and as 216 more sequences become associated with lower levels of the taxonomic range of microbes 217 (Morgan and Huttenhower 2012, Nguyen et al. 2016). Furthermore, horizontal gene transfer 218 (HGT) between distinct taxa may lead to incorrect taxonomic assignments (Pignatelli et al. 219 2008). When comparing a microbial community with an environment, it is important to 220 remember that DNA isolation impacts the structure of the bacterial community. A particular 221 isolation method may be more effective with some taxa but less so with others (Krsek and 222 Wellington 1999, Carrigg et al. 2007).

223 Despite these problems, eDNA can provide a lot of valuable information based on 224 basic molecular techniques. Different tools employing microsatellite DNA, as well as the 
225 mtDNA markers used in forensic genetics, can be used to identify animals based on their

226 traces. Faecal DNA analysis may be potentially valuable for the conservation and

227 management of endangered but rarely encountered species, as molecular techniques are easier

228 to carry out and faster than traditional approaches based on observation, behaviour and 229 trapping.

230 Glacial ice and permafrost are also a source of ancient DNA (aDNA). Studies of 231 aDNA gives us information not only about microorganisms but also about extinct animals, 232 plants and other organisms (Pedersen et al. 2016). The main problems faced by aDNA 233 investigation are low yield, contamination by modern DNA and degradation (Mitchell et al. 234 2005). Using the right procedure and methods, however, and following strict criteria for 235 authentication lower the risk of contamination and false results (Hebsgaard et al. 2005, 236 Thomas et al. 2005). Studies of aDNA isolated from permafrost across the whole Arctic have 237 given us the most extensive historical records of vegetation changes over the past $50 \mathrm{kyr}$ 238 (Willerslev et al. 2014). Different microbial community structures were found in two different 239 permafrost samples of a similar age (Krivushin et al. 2015). It was shown, for example, that 240 bacterial communities from different layers of the Canadian permafrost exhibit divers 241 resistance mechanisms against aminoglycoside, $\beta$-lactam and tetracycline antibiotics (Perron 242 et al. 2015).

\section{Metagenomics in environmental research}

245 Metagenomics is the study of genetic material recovered from microorganisms that 246 cannot be cultured with the use of currently known molecular methods, directly from their 247 natural environment (Handelsman et al. 1998, Daniel 2005, Schloss and Handelsman 2005, 248 Sabree et al. 2009, Thomas et al. 2012). Although metagenomics is still quite a new branch of 249 science and a radical new way of doing microbiology, it has already delivered plenty of 
250 information about uncultured microorganisms. This approach has revealed an enormous 251 diversity of unknown and uncharacterized biochemical pathways, providing biological 252 insights into complex microbial communities (Handelsman et al. 1998, Tyson et al. 2004, 253 Venter et al. 2004). All metagenomics studies have a similar workflow and take the same first 254 step: DNA is extracted directly from all the microbes living in a particular environment 255 (Handelsman et al. 2007). DNA from microorganisms can be extracted from various 256 environments, such as soil, sediments, water, sludge, oral cavity, faeces and skin (e.g. Saano 257 et al. 1995, Snaidr et al. 1997, Daniel 2005, Wexler et al. 2005, Tekere et al. 2011). In the 258 next step, DNA can be sequenced, then directly analysed or cloned into a form maintainable 259 in a laboratory, creating a library that contains the genomes of all the microbes found in that 260 environment (Handelsman et al. 2007).

Recent advances in high-throughput sequencing technologies provide access to the 262 culture-free characterization of microbial community structures in a variety of environments, 263 including soil and faeces. Next Generation Sequencing (NGS) makes it easier and faster to 264 analyse the structure of bacterial communities without the need to clone DNA sequences into 265 a vector (Handelsman et al. 2007). Moreover, metagenomic approaches allow an earlier 266 unidentified microbial DNA to be obtained that can lead to the discovery of new genes 267 encoding proteins with a desired function, for example, resistance to antibiotics, or involved 268 in pollutant degradation (Riesenfeld et al. 2004, Daniel 2005, Zhang and Bennet 2005, 269 Handelsman et al. 2007). Because of our inability to culture as many as $99 \%$ of bacteria using 270 traditional microbiological methods, the direct extraction of microbial DNA from 271 environmental samples has become the method of choice in molecular biology and 272 biotechnology research when it comes, e.g. to estimating microbial biodiversity, searching for 273 genes with a desired function or recognising the relationship between the structure of the 274 genome and the part it plays in a specific environment (Schmidt et al. 1991, Zhou et al. 1996, 
275 Riesenfeld et al. 2004, Daniel 2005, Deja-Sikora et al. 2007, Neelakanta and Sultana 2013).

276 Furthermore, NGS provides an opportunity to analyse low abundance microbial components

277 that contribute to less than $1 \%$ of the total population (Lee et al. 2012).

In microbial ecology, metagenomics is used for describing the taxonomic distribution

279 of microbial community members. In this context, NGS sequence analysis of the 16S rRNA

280 gene becomes the ideal tool for obtaining taxonomic information, often considered to be the

281 'gold standard' as regards bacterial identification; in consequence, the gene sequence has been

282 targeted in countless studies (Rosselli et al. 2016). The 16S rRNA gene is often used in

283 studies of bacterial evolution and ecology, including the determination of phylogenetic

284 relationships among taxa and the exploration of bacterial diversity for several reasons. The

285 most important one is the fact that the gene is universally distributed, which allows one to

286 analyse phylogenetic relationships among distant taxa. Being functionally indispensable, this

287 gene is also highly conserved. Nevertheless, the $16 \mathrm{~S}$ rRNA gene is also variable in certain 288 regions, which allows sufficient diversification and makes it a tool well-suited for

289 classification (Head et al. 1998, Větrovský and Baldrian 2013).

290 Regardless of above, there are several aspects limiting the interpretation of 16S rRNA-

291 derived results. The most important one is the fact that its copy numbers per genome vary

292 from 1 to 15 or more (Klappenbach et al. 2001). Nowadays, moreover, most analyses of

293 bacterial community structures rely on OTU analysis and the construction of similarity

294 clusters of 16S rRNA gene PCR amplicons (Morgan and Huttenhower 2012, Nguyen et al.

295 2016). Consequently, both multiplicity and variability present problems for the assessment of

296 bacterial diversity and community structure, i.e. the relative abundance of individual taxa.

297 Another drawback of 16S rRNA gene analysis is that the presence of DNA may not necessary

298 mean that the organism detected is alive and still present in the environment, especially when 
299

300

301

302

303

304

305

306

307

308

309

310

311

312

313

314

315

316

317

one considers the Arctic environment, where low temperatures can preserve DNA for a long time and the microbial structure obtained may not represent the current microbial community.

A possible solution to this would be to focus on RNA rather than on DNA, as rRNA itself can yield useful information about which community members are currently active (Kamke et al. 2010, Wemheuer et al. 2012). Unfortunately, there are also problems with this approach, as total RNA has to be extracted from an environmental sample, a quite problematic step in itself, and subsequently converted to cDNA. The library for the NGS analysis of $16 \mathrm{~S}$ rRNA amplicons is generated from cDNA, and still dependent on a PCR process, as cDNAs are amplified by universal primers, as is the case in 16S rRNA gene analysis (Kamke et al. 2010, Wemheuer et al. 2012, Rosselli et al. 2016). Furthermore, Rosselli et al. (2016) propose the direct sequencing of $16 \mathrm{~S}$ ribosomal RNA without any primer- or PCR-dependent step in order to overcome the above-mentioned drawbacks. Direct rRNA-seq is based not only on taxon abundance, but also on physiological activity and could be used as a methodology complementary to those mentioned above in microbial community studies (Rosselli et al. 2016).

To date, a series of metagenomics studies has revealed a high diversity of microbes in different niches and, in consequence, improved our understanding of new taxa, their biogeographical distribution and the association of specific microbial groups with geochemical factors (Guan et al. 2013). Moreover, metagenomics approaches allow one to explore the distribution of microbial populations, to compare microbial communities in different environments influenced by various natural or anthropogenic factors, and to monitor the effect of ongoing environmental changes on microbial communities (Neelakanta and Sultana 2013). There are several studies concerning the high Arctic involving metagenomics approaches. Varin et al. (2012) analysed the metagenomes of cyanobacterial mats from Arctic and Antarctic ice shelves using high-throughput pyrosequencing. Their study highlights the 
324 presence of diverse mechanisms of adaptation to cold and other stresses in polar mats, which

325 is connected with the representation of major bacterial groups. Lay et al. (2013) provided

326 insights into the metabolic potential and the active microbial populations that exist in the

327 hypersaline cryoenvironment (Canadian high Arctic) by means of metagenomic analyses of

328 the microbial community and pyrosequencing analyses of the cDNA of its 16S rRNA genes.

329 Pawłowska et al. (2014) used metagenomics approaches to compare the diversity of

330 foraminifera in sediments from the Hornsund fjord (Svalbard) with the diversity of aDNA

331 sequenced from subsurface sediment samples. Also in Svalbard, in the high Arctic, Larose et

332 al. (2013) investigated changes in the microbial community associated with seasonal

333 atmospheric $\mathrm{Hg}$ deposits by using metagenomic approaches to quantify mercury resistance

334 genes in snow samples.

335 Molecular identification based on environmental samples

336 The DNA-based approach for studying the relationships between individuals,

337 populations and species has become an important aspect of molecular ecology and in

338 consequence of conservation genetics and systematics (Hellborg and Ellegren 2002). Many

339 molecular tools have been used to perform molecular identification of both species and

340 individuals, including sex identification, also in the context of their health conditions and food

341 intake. All that information can be a valuable source of data about animals inhabiting a

342 particular area, especially when a small number of individuals live in a large area and their

343 presence is recorded only on the basis of faecal residues. The Y chromosome-linked

344 approach, together with other molecular markers like mtDNA or microsatellite DNA, can also

345 be used for identifying species in the context of animal relatedness in the population, and their

346 relationships within a given environment in the context of its ecological aspects.

347 Ruokonen et al. (2005) used mtDNA analyses to investigate population structure and

348 phylogeography of the pink-footed goose (Anser brachyrhynchus) from breeding areas in 
349 Greenland, Iceland and Svalbard. They indicated that populations of pink-footed goose 350 separated recently (less than 10000 years ago) and that present breeding areas were colonized 351 from one refugial population. Mitochondrial DNA isolated from blood, muscle and feathers 352 collected in breeding areas also supported the concept of three species: the pink-footed goose, 353 breeding in Greenland, Iceland and Svalbard, Middendorff's goose Anser middendorffi 354 breeding in the eastern taiga zone, and the bean goose Anser fabalis, breeding in the western 355 parts of the taiga zone and in the tundra zone of the Palearctic (Ruokonen et al. 2008).

356 Investigation of mtDNA collected from tissue, muscle and skin showed the 357 evolutionary distinction of north-west Greenland walruses from populations in east 358 Greenland, Svalbard and Franz Josef Land. Moreover, microsatellite variation grouped 359 Atlantic walruses into three populations: one in north-west Greenland, another in east 360 Greenland and a common Franz Joseph-Svalbard population (Andersen et al. 1998).

361 The origin of the three small-bodied, high-Arctic subspecies of reindeer were 362 investigated by sequencing the control region of mtDNA from tissue, blood, skin and bone. 363 Rangifer tarandus pearyi from the Canadian Archipelago and Rangifer tarandus 364 groenlandicus from east Greenland (extinct since 1900 AD) were closely related and probably 365 evolved in high-Arctic North America, whereas Rangifer tarandus platyrhynchus from 366 Svalbard evolved from Eurasian large-bodied reindeer (Gravlund et al. 1998). In addition, 367 data from 14 microsatellites were used to characterize the levels of genetic diversity of 368 Svalbard reindeer from two adjacent areas on Nordenskjöldland, Spitsbergen. That study 369 acknowledged the fact that Svalbard reindeer appear to conform to the paradigm of island 370 populations made genetically depauperate by genetic drift (Côté et al. 2002). The Y 371 chromosome-linked approach has already been shown to be useful for sex identification based 372 on Svalbard reindeer faecal samples from the northern part of the Hornsund fjord (Zielińska et 373 al. 2016b). 
This approach, namely the analysis of eDNA from Arctic samples, is also widely used 375 in the identification not only of microbes and fungi (Maccario et al. 2014), but also of

376 potential metabolic responses of microbial communities to environmental stresses (Varin et

377 al. 2012) and their contribution to greenhouse gas emissions (Yergeau et al. 2010).

378 Metagenomics studies of eDNA have been successful in the identification and estimation of

379 plant taxonomic diversity across many climate zones (Yoccoz et al. 2012) and microbial and

380 fungal species present in Arctic snow (Maccario et al. 2014). Moreover, when combined with

381 pollen and macrofossils, the method has proven its worth in the palaeovegetational

382 reconstruction of vegetational changes of Siberian regions from material deposited in

383 permafrost (Jørgsen et al. 2012). Large-scale analysis of eDNA has yielded insight into plant

384 and nematode growth and the diet of herbivorous megafaunal mammals over a time span of

38550000 years in the Arctic (Willerslev et al. 2014). Analysis of DNA from glacier ice enabled

386 multiple taxa of fungi, plants, algae and protists to be identified, a result that could not have

387 been obtained using morphological identification alone (Willerslev et al. 1999). Analysis of

388 deep ice cores obtained from Greenland have revealed a rich source of DNA showing a

389 diverse array of coniferous trees and insects within the past million years of the history of the 390 sampled area (Willerslev et al. 2007).

391

392 Faeces permit non-invasive sampling

393 Over the years, advances in molecular techniques have enabled microbial animal and

394 plant identification at both species and individual levels by DNA analysis based on non-

395 invasive material like faeces, urine, shed hair or feathers (e.g. Taberlet et al. 1997, Kohn et al.

396 1999, Ernest et al. 2000, Flagstad et al. 2004), which are valuable sources of environmental

397 DNA. In ruminants, samples for microbial analysis are usually collected from the rumen

398 (Makkar and McSweeney 2005, Sundset et al. 2007, Lee et al. 2012, Glad et al. 2014). 
399 However, this kind of sampling strategy, though reasonable, can only be performed on a dead 400 animal, otherwise it causes the animal serious stress. Moreover, such sampling methods 401 interfere with the natural animal environment, especially in the case of wild populations with 402 limited or no previous exposure to humans (Zielińska et al. 2016a). In such situations, and 403 also in case of other animal species, testing of faecal samples as a non-invasive sampling 404 strategy can be a good alternative, especially when the fieldwork takes place in wild, 405 uninhabited areas. Faecal samples can provide much valuable information about the symbiotic 406 microorganisms, bacteria, archaea or fungi associated with a particular species or 407 environment.

$408 \quad$ Faecal samples have often been used in traditional cultivation methods for screening 409 bacteria of potentially pathogenic significance to humans. The barnacle goose Branta 410 leucopsis, a migratory bird, was tested as a potential carrier of virulent strains of Escherichia 411 coli into the Arctic environment (Hatha et al. 2013). With the use of traditional cultivation 412 methods combined with molecular techniques, cloacal swabs and faeces samples of wild birds 413 from Arctic Svalbard (Norway) were analysed for Escherichia coli and Enterobacter cloacae 414 isolates, resistant to cephalosporins and fluoroquinolones, and for Salmonella isolates. As a 415 result, a novel variant of the $\operatorname{ampC}$ beta-lactamase gene (blaACT-23) was revealed (Literak et 416 al. 2014). Also, molecular techniques revealed shiga toxin genes from pathogenic E. coli in 417 Svalbard reindeer faeces (Zielińska et al. 2016b).

418 A study of pathogenic yeasts in cloacal swabs from the little auk (Alle alle) suggested 419 that this seabird is a random carrier of such yeasts (Dynowska et al. 2013). Nonetheless, 420 owing to the specific composition of faeces, the range of applicability of certain analytical 421 techniques like metagenomic analysis is limited. In our experience, extraction of good quality 422 DNA can be very difficult, and is even impossible at present for some bird species: this is 
423 because of the strong enzymatic inhibitors present in birds' faecal, and sometimes because the 424 sample is too small.

425 Faeces can also be a valuable source of information about microorganism 426 composition. Metagenomic approaches were used to investigate bacterial diversity in polar 427 bear faeces (Ursus maritimus) from Svalbard (Glad et al. 2010). With the aid of the 16S 428 rRNA gene clone library, they studied the microbial structure of the bear's gut, hitherto little 429 known. They also investigated the bla 430 potential natural reservoir of those clinically important genes. In another study, bacterial 431 population structure was investigated using Next Generation Sequencing (NGS) 16S rDNA 432 analysis of faecal samples from the endemic population of Svalbard reindeer in the northern 433 part of the Hornsund fjord (Zielińska et al. 2016a).

434 DNA extracted from faeces can be used as a comprehensive and non-invasive tool in 435 order to establish the diet of the animals under scrutiny. DNA barcoding (species 436 identification using a standardized DNA sequence), together with the availability of DNA 437 sequencing techniques, presents new opportunities in animal diet analysis. DNA fragments, 438 often degraded and shorter than 100-150 bp, are easily found in faeces. By using universal 439 primers for amplifying very short but informative DNA fragments, one can identify not only 440 food components of animal origin but also the plant taxa that had been consumed. Even so, 441 identification of prey using this method can be quite challenging and is not always precise.

442 Such analyses, e.g. mtDNA analysis of prey items employed to establish animal feeding 443 ecology, have been useful for research into many bird species, like Adelie penguins 444 (Pygoscelis adeliae) (Jarman et al. 2002), Macaroni penguins (Eudyptes chrysolophus) and 445 little penguins (Eudyptula minor) (Deagle et al. 2007, 2010).

446 Joo et al. (2014) applied length-heterogeneity analysis by PCR (LH-PCR) based on 447 length differences of internal transcribed spacer (ITS) regions of ribosomal RNA (rRNA) to 
448 study foraging preference on Svalbard from Ny-Alesund, north-west Spitsbergen, on the basis

449 of faecal samples. They demonstrated that this approach could solve a number of difficulties

450 typically encountered in conventional sampling methods. In order to do so, they created a 451 length-heterogeneity (LH) database from samples of potential food sources of Svalbard 452 reindeer and of their faeces. Detailed and accurate information on foraging preferences in 453 accordance with seasonal and regional characteristics can help to understand the energy 454 requirements of Svalbard reindeer, which are related to the quality and quantity of the food 455 they ingest. These authors suggest that LH-PCR for faecal dietary analysis would be an 456 efficient, non-invasive monitoring tool for characterizing the foraging strategy of Svalbard 457 reindeer. This approach could also be used for other Arctic animals in order to obtain 458 comprehensive dietary information based only on field-collected faecal samples. Such 459 samples can thus be treated as valuable sources of information, delivering comprehensive data 460 about the identity of a species as well as its genetic history, microbiome (also specific genes) 461 and diet.

462

\section{Soil microbiology}

Soil is often described as the most challenging of all natural environments with regard to DNA extraction and analysis, mostly because of the diversity of species present in it, especially microorganisms, and the variety of enzymatic inhibitors, like humic acids or heavy

467 metals. Soil can also contain mineral particles of different size or origin, as well as organic 468 compounds that can be at various stages of decomposition (Daniel 2005). In the soil 469 environment, microorganisms (such as bacteria and fungi) play an extremely important role in 470 decomposing dead organic matter and in the nutrient cycle generally. Any adverse changes to 471 soil parameters, such as pollution, $\mathrm{pH}$, temperature and biomass, can disrupt the nutrient 
472 cycle, which may have an impact on the functioning of the whole ecosystem (Stefanowicz et 473 al. 2009).

474 Studying the microbial communities of the Arctic can be a valuable source of 475 information about how that ecosystem functions. Many studies have focused on determining 476 the microbial community structure and its relationship with changing soil properties, not only 477 in the Arctic (Campbell et al. 2010, Ramirez et al. 2010, Kim et al. 2014). Owing to the harsh 478 environmental conditions, microbial communities in the Arctic soil were expected to have a 479 poor diversity of bacterial species, but in fact they are as diverse as those found in other 480 biomes (Koyama et al. 2014). Moreover, Chu et al. (2010) demonstrated that the bacterial 481 communities of Arctic soils have similar levels of variability, richness and phylogenetic 482 diversity as soils from a wide range of lower latitudes, which suggests a common diversity of 483 structure within soil bacterial communities around the globe. These authors concluded that 484 Arctic soil bacterial communities are strongly influenced by local environmental factors, 485 especially those associated with soil acidity, similar to what was observed for the fungal 486 community composition in this high Arctic region (Zhang et al. 2016). In addition, 487 cyanobacteria communities depend not only on soil crust development but on $\mathrm{pH}$, ammonium 488 and organic carbon concentrations: a higher $\mathrm{pH}$ and a lower concentration of total organic 489 carbon resulted in a lower cyanobacteria richness (Pushkareva et al. 2015). Mackelprang et al. (2016) indicated that the striking differences in bacterial 491 composition and diversity among different permafrost locations might be due to stark 492 variations in permafrost chemistry, mineralogy and ice content. Furthermore, Allison and 493 Martiny (2008) imply that changes in microbial composition are often associated with 494 changes in ecosystem process rates. Thus, changes in microbial communities resulting from 495 disturbances may directly affect ecosystem processes. Establishing these relationships can 496 determine how easily the microbial community composition can be used to predict the 
497 responses of the ecosystem to global change. The same appears to apply to root-associated 498 fungal communities, where no relationships between them and above-ground Arctic 499 vegetation were found (Mundra et al. 2015). The richness of root-associated fungal increased 500 with host root weight and length (Mundra et al. 2015). The fungal community structure 501 depended on the $\mathrm{pH}, \mathrm{C}: \mathrm{N}$ ratio and available phosphorus (Fujimura and Egger 2011).

502 Microorganisms mediate crucial biogeochemical cycles of nitrogen and carbon in cold 503 environments (Makhalanyane et al. 2016). Thus, knowledge of soil microbial community 504 structures and functions is important for predicting the response of Arctic terrestrial 505 ecosystems to climate changes. It has been shown that changes in Arctic peat soil microbiota 506 were temperature-dependent. Above $7^{\circ} \mathrm{C}$ a shift was observed where Firmicutes were 507 replaced by Bacteriodetes. This was evidence for the rapid adaptation of microbial 508 communities to increasing temperatures and their influence on $\mathrm{CH}_{4}$ production (Tviet et al. 509 2015). In Alaska, too, the microbial communities of the permafrost respond to thawing by 510 rapidly stimulating enzymatic activity, which decomposes organic matter in the soil 511 (Mackelprang et al. 2011, Coolen and Orsi, 2015).

512 Nonetheless, studies on Spitsbergen have shown no significant differences in the high 513 taxonomic ranks of bacterial structure communities between areas intensively fertilized by the

514 little auk colony, characterized by high levels of nutrients and organic matter biomasses, and 515 the control area (Zielińska et al. 2016c). In this case, different physicochemical features of the 516 soil had no substantial impact on the general bacterial community structure, at least at higher 517 taxonomic ranks.

Conclusions

Owing to the harsh climate, presence of permafrost, short growing season, strong 521 seasonality and rapid climate changes, studying Arctic ecosystems is a high-priority issue 
522 (Gough et al. 2016, Makhalanyane et al. 2016). Their current state and functioning need to be

523 known and understood in order to monitor changes and their influence on particular aspects of

524 the ecosystem. Ecological relationships and climate-induced changes in ecosystems can be

525 monitored faster and more easily using molecular approaches such as metagenomics or

526 environmental DNA techniques. Molecular techniques enable species to be identified and

527 even whole population structures to be established on the basis of environmental DNA

528 samples. By combining molecular and ecological techniques one can acquire detailed

529 information about plants and the individual features of animals, including their diet and

530 symbiotic microorganisms. Even though there are potential problems with the analysis of

531 DNA from environmental samples, molecular approaches can be a valuable supplementary

532 source of information about the structure and functioning of the Arctic ecosystem in the 533 course of transformation.

\section{Acknowledgements}

536 This work was supported by the National Science Centre, Poland (grant No.

537 2014/15/N/NZ9/03882, 2011/01/D/NZ2/04817 and 2011/01/N/NZ8/04569).

539 References

540 Aislabie, J., Jordan, S., Ayton, J., Klassen, J.L., Barker, G.M., Turner, S. 2009. Bacterial

541 diversity associated with ornithogenic soil of the Ross Sea region. AntArctica. Can. J.

542 Microbiol. 55: 21-36.

543 Allison, S.D., and Martiny, J.B.H. 2008. Resistance, resilience, and redundancy in microbial 544 communities. PNAS 105: 11512-19.

545 Andersen, N.W., Born, E. W., Gjertz, I., Wiig, O., Holm, L.E., Bendixen C. 1998. Population 546 structure and gene flow of the Atlantic walrus (Odobenus rosmarus rosmarus) in the eastern 
547 Atlantic Arctic based on mitochondrial DNA and microsatellite variations.Mol. Ecol.

$548 \quad 7(10): 1323-36$.

549 ABA. 2013. Arctic Biodiversity Assessment. Conservation of Arctic Flora and Fauna

550 (CAFF). Akureyri, Iceland. pp. 559.

551 ACIA. 2005. Arctic Climate Impact Assessment. ACIA Overview report. Cambridge

552 University Press, Cambridge, UK. pp. 1020.

553 AMAP. 2011. Snow, Water, Ice and Permafrost in the Arctic (SWIPA): Climate Change and

554 the Cryosphere. Arctic Monitoring and Assessment Programme (AMAP), Oslo, Norway. pp. $555 \quad 538$.

556 Brinkman, T.J., Person, D.K., Schwartz, M.K., Pilgrim, K.L., Colson, K.E., Hundertmark,

557 K.J. 2010. Individual identification of Sitka black-tailed deer (Odocoileus hemionus sitkensis)

558 using DNA from fecal pellets. Conserv. Genet. Resour. 2:115-118.

559 Callaghan, T.V., Jonasson, S., Nichols, H., Heywood, R.B., Wookey, P.A. 1995. Arctic

560 Terrestrial Ecosystems and Environmental Change. Phil. Trans. R. Soc. Lond. A. 352: 259-

561276.

562 Campbell, B.J., Polson, S.W., Hanson, T.E., Mack, M.C., Schuur, E.A. 2010. The effect of

563 nutrient deposition on bacterial communities in Arctic tundra soil. Environ. Microbiol. 12

564 (7):1842-54.

565 Carrigg, C., Rice, O., Kavanagh, S., Collins, G., O’Flaherty, V. 2007 DNA extraction method

566 affects microbial community profiles from soils and sediment. Appl. Microbiol. Biotechnol.

$567 \quad 77: 955-964$. 
568 Chu, H., Fierer, N., Lauber, C.L., Caporaso, J.G., Knight, R., Grogan, P. 2010. Soil bacterial

569 diversity in the Arctic is not fundamentally different from that found in other biomes.

570 Environ. Microbiol. 12: 2998-3006.

571 Cole, J.R., Wang, Q., Cardenas, E., Fish, J., Chai, B., Farris, R.J., Kulam-Syed-Mohideen,

572 A.S., McGarrell, D.M., Marsh, T., Garrity, G.M., Tiedje, J.M. 2009. The Ribosomal Database

573 Project: improved alignments and new tools for rRNA analysis. Nucleic Acids Res. 37:

574 D141-145.

575 Coolen, M.J.L., and Orsi, W.D. 2015. The transcriptional response of microbial communities

576 in thawing Alaskan permafrost soil. Front. Microbiol. 6: 197, 1-14.

577 Cooper, E.J. 2014. Warmer shorter winters disrupt Arctic terrestrial ecosystems. Annu. Rev.

578 Ecol. Evol. Syst.45: 271-295.

579 Convey, P., Chown, S., Clarke, A., Barnes, D.K.A., Bokhorst, S., Cummings, V., Ducklow,

580 H.W., Frati, F., Green, T.G.A., Gordon, S., Griffiths, H.J., Howard-Williams, C., Huiskes,

581 A.H.L., Laybourn-Parry, J., Lyons, W.B., Mcminn, A., Morley, S.A., Peck, L.S., Quesada,

582 A., Robinson, S.A., Schiaparelli, S., Wall, D.I.H. 2014. The spatial structure of Antarctic

583 biodiversity. Ecol. Monograph., 84(2): 203-244.

584 Côté, S.D., Dallas, J.F., Marshall, F., Irvine, R.J., Langvatn, R., Albon, S.D. 2002.

585 Microsatellite DNA evidence for genetic drift and philopatry in Svalbard reindeer. Mol. Ecol.

$58611(10): 1923-30$.

587 Coulson, S.J ., Convey, P., Aakra, K., Aarvik, L., Ávila-Jiménez, M.L., Babenko, A.,

588 Biersma, E.M., Boström, S. ., Brittain, J.E ., Carlsson, A.M., Christoffersen, K., De Smet,

589 W.H., Ekrem, T., Fjellberg, A., Füreder, L., Gustafsson, D., Gwiazdowicz, D.J., Hansen,

590 L.O., Holmstrup, M., Hullé, M., Kaczmarek, Ł., Kolicka, M., Kuklin, V., Lakka, H.-K.,

591 Lebedeva, N., Makarova, O., Maraldo, K.,Melekhina, E., Ødegaard, F. ., Pilskog, H.E, Simon,

592 J.C., Sohlenius, B., Solhøy, T., Søli, G., Stur, E., Tanasevitch, A. Taskaeva, A., Velle, G., 
593 Zawierucha, K. Zmudczyńska-Skarbek. K. 2014. The terrestrial and freshwater invertebrate

594 biodiversity of the archipelagoes of the Barents Sea; Svalbard, Franz Josef Land and Novaya 595 Zemlya, Soil Biol. Biochem.68: 440-470.

596 Coulson, S.J. 2007. Terrestrial and Freshwater Invertebrate Fauna of the High Arctic

597 Archipelago of Svalbard. Zootaxa 1448:41-58.

598 Cowan, D.A., Ramond, J.-B., Makhalanyane, T.P., De Maayer, P. 2015. Metagenomics of 599 extreme environments (Review). Curr. Opin. Microb. 25: 97-102.

600 Croll, D.A., Maron, J.L., Estes, J.A., Danner, E.M., Byrd, G.V. 2005. Introduced predators 601 transform subarctic islands from grassland to tundra. Science 307: 1959-61.

602 Daniel, R. 2005. The metagenomics of soil. Nat. Rev. Microbiol. 3:470-478.

603 Danks, H.V., and Smith, A.B.T. Insect Biodiversity in the Nearctic Region. 2009. Foottit 604 R.G., Adler P.H. (eds) Insect Biodiversity: Science and Society, pp. 33-48.

605 Deagle, B.E., Chiaradia, A., McInnes, J., Jarman, S.N. 2010. Pyrosequencing faecal DNA to 606 determine diet of little penguins: is what goes in what comes out? Conserv. Genet. 11: 20396072048.

608 Deagle, B.E., Gales, N.J., Jarman, S.N., Robinson, S., Trebilco, R., Hindell, M.A. 2007.

609 Studying Seabird diet through genetic analysis of faeces: a case study on macaroni penguins 610 (Eudyptes chrysolophus). PLoS One. 2: e831.

611 Deja-Sikora, E., Sikora. M., Gołębiewski, M., Tretyn A. 2007. Metagenomic libraries as 612 sources of genes useful for biotechnology. Biotechnologia. 4 (79): 125-139.

613 DeSantis, T.Z., Hugenholtz, P., Larsen, N., Rojas, M., Brodie, E.L., et al. 2006. Greengenes, a 614 chimera-checked 16S rRNA gene database and workbench compatible with ARB. Appl. 615 Environ. Microbiol. 72: 5069-5072. 
616 Descamps, S., Aars, J., Fuglei, E., Kovacs, K.M., Lydersen, C., Pavlova, O., Pedersen, Å.Ø.,

617 Ravolainen, V., Strøm, H. 2016. Climate change impacts on wildlife in a high Arctic

618 archipelago - Svalbard, Norway. Glob. Change. Biol. doi:10.1111/gcb.13381.

619 Dynowska, M. Wojczulanis-Jakubas, K., Pacyńska, J.A., Jakubas, D., Ejdys, E.2013.

620 Potentially pathogenic yeast isolated from the throat and cloaca of an Arctic colonial seabird:

621 the little auk (Alle alle). Polar Biol. 36: 343-348.

622 Eamer, J., et.al. 2013. Life Linked to Ice: A guide to sea-ice-associated biodiversity in this

623 time of rapid change. CAFF Assessment Series No. 10. Conservation of Arctic Flora and

624 Fauna, Iceland. ISBN: 978-9935-431-25-7.

625 Ernest, H.B., Penedo, M.C.T., May, B.P., Syvanen, M, Boyce, W.M. 2000. Molecular

626 tracking of mountain lions in the Yosemite Valley region in California: genetic analysis using

627 microsatellites and faecal DNA. Mol. Ecol. 9: 433-441.

628 Flagstad, Ø., Hedmark, E., Landa, A., Broseth, H., Persson, J., Andersen, R., Segersrom, P.,

629 Ellegren, H. 2004. Colonization history and noninvasive monitoring of a re-established

630 wolverine population. Conserv. Biol. 18: 676-688.

631 Fujimura, K.E., and Egger, K.N. 2011. Host plant and environment influence community

632 assembly of High Arctic root-associated fungal communities. Fungal Ecol. 5: 409-418.

633 Gough, L., Bettez, N.D., Slavik, K.A., Bowden, W.B., Giblin, A.E., Kling, G.W., Laundre,

634 J.A, Shaver G.R. 2016. Effects of long-term nutrient additions on Arctic tundra, stream, and

635 lake ecosystems: beyond NPP. Oecologia, doi:10.1007/s00442-016-3716-0.

636 Gharajehdaghipour, T., Roth, J.D., Fafard, P.M., Markham, J.H. 2016. Arctic foxes as

637 ecosystem engineers: increased soil nutrients lead to increased plant productivity on fox dens.

638 Sci. Rep. 6: 24020. 
639 Gilg, O., Kovacs, K.M., Aars, J., Fort, J., Gauthier, G., Grémillet, D., Ims, R.A., Meltofte, H., 640 Moreau, J., Post, E., Schmidt, N.M., Yannic, G., Bollache, L. 2012. Climate change and the 641 ecology and evolution of Arctic vertebrates. Ann. NY. Acad. Sci. 1249: 166-190.

642 GISTEMP Team. 2016: GISS Surface Temperature Analysis (GISTEMP). NASA Goddard 643 Institute for Space Studies. Dataset accessed 2016-04-20 at http://data.giss.nasa.gov/gistemp/.

644 Glad, T., Barboza, P., Mackie, R.I., Wright, A.D., Brusetti, L., Mathiesen, S.D., Sundset, 645 M.A. 2014. Dietary Supplementation of Usnic Acid, an Antimicrobial Compound in Lichens, 646 Does Not Affect Rumen Bacterial Diversity or Density in Reindeer. Curr. Microbiol. 68: 724 $647 \quad 728$.

648 Glad, T., Bernhardsen, P., Nielsen, K.M., Brusetti, L., Andersen, M., Aars, J., Sundset, M.A. 649 2010. Bacterial diversity in faeces from polar bear (Ursus maritimus) in Arctic Svalbard. 650 BMC Microbiol. 14: 10:10.

651 Goode, M. J. 2011. Capture-recapture of white-tailed deer using DNA sampling from fecal 652 pellet-groups. M.Sc. thesis, University of Tennessee.

653 Gravlund, P., Meldgaard, M., Paabo, S., Arctander, P. 1998. Polyphyletic Origin of the Small654 Bodied, High-Arctic Subspecies of Tundra Reindeer (Rangifer tarandus). Mol. Phylogent. 655 Evol. 10:151-159.

656 Grémillet, D., Boulinier, T. 2009. Spatial ecology and conservation of seabirds facing global 657 climate change: a review. Mar. Ecol. Prog. Ser. 391: 121-137.

658 Grzesiak, J., Górniak, D., Świątecki, A., Aleksandrzak-Peikarczyk T., Szatraj K. 2015.

659 Extremophiles 19: 885. doi:10.1007/s00792-015-0764-Z. 
660 Guan, X., Wang, J., Zhao, H., Wang, J., Luo, X., Liu, F., Zhao, F. 2013. Soil bacterial

661 communities shaped by geochemical factors and land use in a less-explored area, Tibetan

662 Plateau. BMC Genomics. 14:820.

663 Hansen, J.R., Ruedy, M. Sato, Lo, K. 2010. Global surface temperature change, Rev.

664 Geophys. 48: RG4004. doi:10.1029/2010RG000345.

665 Handelsman, J., Rondon, M. R., Brady, S. F, Clardy, J., Goodman, R. M. 1998. Molecular

666 biological access to the chemistry of unknown soil microbes: a new frontier for natural

667 products. Chem. Biol. 5, R245-R249.

668 Handelsman, J., et al. (Committee on Metagenomics: Challenges and Functional Applications,

669 National Research Council). 2007. The New Science of Metagenomics: Revealing the Secrets

670 of Our Microbial Planet. The National Academies Press, Washington, DC.

671 Hatha, A.A.M, Divya, P. S., Saramma, A. V., Rahiman, M., Krishnan, K. P. 2013. Migratory

672 bird, Branta leucopis (Barnacle goose), a potential carrier of diverse Escherichia coli

673 serotypes into pristine Arctic environment. Curr. Sci.: 104:8.

674 Head, I.M., Saunders, J.R., Pickup, R.W. 1998. Microbial evolution, diversity, and ecology: A

675 decade of ribosomal RNA analysis of uncultivated microorganisms. Microb. Ecol. 35: 1-21.

676 Hebsgaard, M.B., Phillips, M.J., Willerslev, E. 2005. Geologically ancient DNA: fact or

677 artefact. Trends Microbiol. 13 (5): 212-20.

678 Hellborg, L., and Ellegren, Y.H. 2003. Chromosome conserved anchored tagged sequences

679 (YCATS) for the analysis of mammalian male-specific DNA. Mol. Ecol. 12: 283-291.

680 Hiraoka, S., Yang, C., Iwasaki, W. 2016. Metagenomics and bioinformatics in microbial

681 ecology: current status and beyond. MicrobesMicrobs. Environ. 31(3): 204-212. 
682 Jakubas, D., Zmudczyńska, K., Wojczulanis-Jakubas, K., Stempniewicz, L. 2008. Faeces

683 deposition and numer of vertebrate herbivores in the vicinity of planktivorus and piscivorus 684 seabirds colonies inHordsund, Spitsbergen. Pol. Polar Res. 29: 45-58.

685 Jarman, S.N., Gales, N.J., Tierney, M., Gill, P.C., Elliott, N.G. 2002. A DNA-based method 686 for identification of krill species and its application to analyzing the diet of marine vertebrate 687 predators. Mol. Ecol. 11: 2679-2690.

688 Joo, S., Han, D., Lee, E.J., Park, S. 2014. Use of length heterogeneity polymerase chain 689 reaction (LH-PCR) as non-invasive approach for dietary analysis of Svalbard reindeer, 690 Rangifer tarandus platyrhynchus. PLoS One. 11:9: e91552. doi:

691 10.1371/journal.pone.0091552. eCollection 2014.

692 Jørgensen, T., Haile, J., Moller, P., Andreev, A., Boessenkool, S., Rasmussen, M., Kienast, F., 693 Coissac, E., Taberlet, P., Brochmann, C., Biegelow, N. H., Andersen, K., Orlando, L., Gilbert, 694 M. T. P., Willeslev, E. 2012. A comparative study of ancient sedimentary DNA, pollen and 695 macrofossils from permafrost sediments of northern Siberia reveals long-term vegetational 696 stability. Molecular Ecology, 21: 1989-2003. doi:10.1111/j.1365-294X.2011.05287.x

697 Kamke, J., Taylor, M. W., Schmitt, S. 2010. Activity profiles for marine sponge-associated 698 bacteria obtained by $16 \mathrm{~S}$ rRNA vs $16 \mathrm{~S}$ rRNA gene comparisons. ISME J. 4: 498-508.

699 Kim, H.M., Jung, J.Y., Yergeau, E., Hwang, C.Y., Hinzman, L., Nam, S., Hong, S.G., Kim, 700 O.S., Chun, J., Lee, Y.K. 2014. Bacterial community structure and soil properties of a 701 subarctic tundra soil in Council, Alaska. FEMS Microbiol. Ecol. 8: 465-75.

702 Kim, M., and Wuertz, S. 2015. Survival and persistence of host-associated Bacteroidales cells 703 and DNA in comparison with Escherichia coli and Enterococcus in freshwater sediments as 704 quantified by PMA-qPCR and qPCR. Water Res. 15, 87:182-92. 
705 Klappenbach, J.A., Saxman, P.R., Cole, J.R., Schmidt, T.M. 2001. rrndb: the Ribosomal RNA

706 Operon Copy Number Database. Nuc Acid Res 29: 181-184.

707 Kohler, J., and Aanes, R. 2004. Effect of winter snow and ground-icing on a Svalbard

708 reindeer population: Results of a simple snowpack model. Arc. Antarct. Alp Res. 36(3):333-

709341.

710 Koyama, A., Wallenstein, M.D., Simpson, R.T., Moore, J.C. 2014. Soil bacterial community

711 composition altered by increased nutrient availability in Arctic tundra soils. Front. Microbiol.

712 5: 516, 1-16.

713 Krivushin, K., Kondrashov, F., Shmakova, L., Tutukina, M., Petrovskaya, L., Rivkina, E.

714 2015. Two metagenomes from late Pleistocene northeast Siberian permafrost. Genome

715 Announc. 3 (1): 01380-14.

716 Krsek, M., and Wellington, E.M.H. (1999) Comparison of different methods for the isolation

717 and purification of total community DNA from soil. J. Microbiol. Meth.39: 1-16.

718 Kohn, M.H., York, E.C., Kamradt, D.A., Haught, G., Sauvajot, R.M., Wayne, R.K. 1999.

719 Estimating population size by genotyping faeces. P. Roy. Soc. Lond. B-Biol. 266: 657-663.

720 Larose, C., Prestat, E., Cecillon, S., Berger, S., Malandain, C., Lyon, D., Ferrari, C.,

721 Schneider, D., Dommergue, A., Vogel, T.M. 2013. Interactions between snow chemistry,

722 mercury inputs and microbial population dynamics in an Arctic snowpack. PLoS One.

723 8(11):e79972. doi: 10.1371/journal.pone.0079972. eCollection 2013.

724 Lay, C.Y., Mykytczuk, N.C., Yergeau, É., Lamarche-Gagnon, G., Greer, C.W., Whyte, L.G.

725 2013. Defining the functional potential and active community members of a sediment

726 microbial community in a high-arctic hypersaline subzero spring. Appl. Environ. Microbiol.

727 79(12):3637-48. doi: 10.1128/AEM.00153-13. Epub 2013 Apr 5. 
728

729

730

731

732

733

734

735

736

737

738

739

740

741

742

743

744

745

746

747

748

749

Lee, H.J., Jung,I.Y., Oh, J.K., Lee, S-S., Madsen, E.L., Jeon, C.O. 2012. Comparative Survey of Rumen Microbial Communities and Metabolites across One Caprine and Three Bovine Groups, Using Barcoded Pyrosequencing and H Nuclear Magnetic Resonance Spectroscopy. Appl. Environ. Microbiol. 78 17: 5983-5993.

Liu, R., Cheng, K.H., Wong, K., Cheng, S.C., Lau, S.C. 2015. Differential utility of the Bacteroidales DNA and RNA markers in the tiered approach for microbial source tracking in subtropical seawater. Appl. Microbiol. Biotechnol. 99(13):5669-81.

Literak, I., Manga, I., Wojczulanis-Jakubas, K., Chroma, M., Jamborova, I., Dobiasova, H., Sedlakova, M.H., Cizek, A. 2014. Enterobacter cloacae with a novel variant of ACT AmpC beta-lactamase originating from glaucous gull (Larus hyperboreus) in Svalbard. Vet Microbiol. 171(3-4):432-5.

Maccario, L., Vogel, T.M., Larose, L. 2014. Potential Drivers of Microbial Community Structure and Function in Arctic Spring Snow. Frontiers in Microbiology 5: 413.

Mächler, E., Deiner, K., Steinmann, P., Altermatt, F. 2013. Utility of environmental DNA for monitoring rare and indicator macroinvertebrate species. Freshw. Scie.33(4):1174-1183.

Mackelprang, R., Waldrop, M.P., DeAngelis, K.M., David, M.M., Chavarria, K. L., Blazewicz, S.J., Rubin, E.N., Jansson, J.K. 2011. Metagenomic analysis of a permafrost microbialcommunity reveals a rapid response to thaw. Nature. $480: 368-371$.

Mackelprang, R., Saleska, S.R., Jacobsen, S.R., Jansson, J.K., Tass, N. 2016. Permafrost Meta-Omics and Climate Change. Annu. Rev. Earth Planet. Sci. 2016. 44:439-62.

Makkar, H.P.S., and McSweeney, C.S. eds. 2005. Methods in gut microbial ecology for ruminant, Springer, Dordrecht, The Neederlands. 
750 Makhalanyane, T.P., Van Goethem, M.W., Cowan, D.A. 2016. Microbial diversity and

751 functional capacity in polar soils. Curr. Opin. Biotech. 38: 159-166.

752 Marusik, Y.M., Koponen, S., Makarova, O.L. A survey of spiders (Araneae) collected on the 753 arctic island of Dolgiy $\left(69^{\circ} 12^{`} \mathrm{~N}\right)$, Barents Sea. 2016 Arachnology 17: 10-24.

754 Meltofte, H. (ed). 2013. Arctic Biodiversity Assessment. Status and trends in Arctic

755 biodiversity. Conservation of Arctic Flora and Fauna, Akureyri.

756 Mitchell, D., Willerslev, E., Hansen, A. 2005. Damage and repair of ancient DNA. Mutation 757 Research 571: 265-276.

758 Moe, B., Stempniewicz, L., Jakubas, D., Angelier, F., Chastel, O., Dinessen, F., Gabrielsen,

759 G.W., Hanssen, F., Karnovsky, N., Rønning, B., Welcker, J., Wojczulanis-Jakubas, K., Bech,

760 C. 2009. Climate change and phenological responses of two seabird species breeding in the

761 high-Arctic. Mar. Ecol. Prog. Ser. 393:235-246.

762 Morgan, X.C., and Huttenhower, C. 2012. Chapter 12: Human Microbiome Analysis. PLoS

763 Comput Biol. 8(12): e1002808. doi: 10.1371/journal.pcbi.1002808.

764 Mundra, S., Halvorsen, R., Kauserud, H., Muller, E., Vik, U., Eidesen, P. 2015. Arctic fungal

765 communities associated with roots of Bistorta vivipara do not respond to the same fine-scale

766 edaphic gradients as the aboveground vegetation. New Phytologist. 205:1587-1598.

767 Musilova, M., Tranter, M., Bennett, S.A., Wadham, J., Anesio, A.M. 2015.

768 Stable microbial community composition on the Greenland Ice Sheet

769 Front. Microbiol. DOI: 10.3389/fmicb.2015.00193.

770 Neelakanta, G., and Sultana, H. 2013. The Use of Metagenomic Approaches to Analyze

771 Changes in Microbial Communities. Microbiol. Insights. 6: 37-48. doi: 10.4137/MBI.S10819. 
772 Nguyen, N-P., Warnow, T., Pop, M.,White, B. 2016. A perspective on 16S rRNA operational

773 taxonomic unit clustering using sequence similarity. npj Biofilms and Microbiomes, 16004.

774 Oechel, W.C. 1997. Global change and arctic terrestrial ecosystems. Ecological Studies 124.

775 doi: 10.1007/978-1-4612-2240-8.

776 Palkopoulou, E., Mallick, S., Skoglund, P., Enk, J., Rohland, N., Li, H., Omrak, A.,

777 Vartanyan, S., Poinar, H., Götherström, A., Reich, D., Dalén, L. 2015. Complete genomes

778 reveal signatures of demographic and genetic declines in the woolly mammoth. Curr. Biol. 18, 779 25(10):1395-400. doi: 10.1016/j.cub.2015.04.007.

780 Pawłowska, J., Lejzerowicz, F., Esling, P., Szczuciński, W., Zajączkowski, M., Pawlowski, J. 781 2014. Ancient DNA sheds new light on the Svalbard foraminiferal fossil record of the last 782 millennium. Geobiology. 12(4):277-88. doi: 10.1111/gbi.12087. Epub 2014 Apr 15.

783 Pedersen, M.W., Overballe-Petersen, S., Ermini, L., Sarkissian, C.D., Haile, J., Hellstrom, M., 784 Spens, J., Thomsen, P.F., Bohmann, K., Cappellini, E., Schnell, I.B., Wales, N.A., Carøe, C., 785 Campos, P.F., Schmidt, A.M., Gilbert, M.T., Hansen, A.J., Orlando, L., Willerslev, E.2016. 786 Ancient and modern environmental DNA. Phil. Trans. R. Soc. B 370: 20130383.

787 Perron, G.G., Whyte, L., Turnbaugh, P. J., Goordial, J., Hanage, W. P., Dantas, G., Desai, M.

788 M. 2015. Functional characterization of bacteria isolated from ancient arctic soil exposes 789 divers resistance mechanisms to modern antibiotics. PLoS ONE 10(3): e0069533. 790 doi:10.1371/journal.pone.0069533.

791 Pignatelli, M., Aparicio, G., Blanquer, I., Hernandez, V., Moya, A., Tamames, J. 2008.

792 Metagenomics reveals our incomplete knowledge of global diversity. Bioinformatics. $793 \quad 24: 2124-2125$. 
794 Post, E., and Forchammer, M.C. 2008. Climate change reduces reproductive success of an

795 Arctic herbivore through trophic mismatch. Phil. Trans. R. Soc. B 363: 2367-2373.

796 Pruesse, E., Quast, C., Knittel, K., Fuchs, B.M., Ludwig, W., et al. 2007. SILVA: a

797 comprehensive online resource for quality checked and aligned ribosomal RNA sequence data

798 compatible with ARB. Nucleic Acids Res. 35: 7188- 7196.

799 Pushkareva, E., Pessi, I.S., Wilmotte, A., Elster, J. 2015. Cyanobacterial community

800 composition in Arctic soil crusts at different stages of development. FEMS Microbiol. Ecol.

801 91:fiv143.

802 Ramirez, K.S., Lauber, C.L., Knight, R., Bradford, M.A., Fierer, N. 2010. Consistent effects

803 of nitrogen fertilization on soil bacterial communities in contrasting systems.

804 Ecol.91(12):3463-70.

805 Remmert H. 1980. Arctic Animal Ecology. Springer Verlag. Berlin-Heidelberg-New York, $806 \quad 250 \mathrm{pp}$.

807 Riesenfeld, C.S., Goodman, R.M., Handelsman, J. 2004. Uncultured soil bacteria are a

808 reservoir of new antibiotic resistance genes. Environ. Microbiol. 6: 981-989.

809 Rosselli, R., Romoli,O., Vitulo, N., Vezzi, A., Campanaro, S., de Pascale,F., Schiavon, R.,

810 Tiarca, M., Poletto, F., Concheri,G., Valle, G., Squartinia, A. 2016. Direct 16S rRNA-seq

811 from bacterial communities: a PCR-independent approach to simultaneously assess microbial

812 diversity and functional activity potential of each taxon. Sci. Rep. 2016; 6: 32165. doi:

$813 \quad 10.1038 /$ srep32165.

814 Ruokonen, M., Aarvak, T., Madsen, J. 2005. Colonization history of the high-arctic pink-

815 footed goose Anser brachyrhynchus. Mol. Ecol. 14 1:171-8. 
816 Ruokonen, M., Litvin K., Aarvak T. 2008. Taxonomy of the bean goose-pink-footed goose. 817 Mol Philogenet Evol48, 554-562.

818 Saano, A., Tas, E., Pippola, S., Lidstorm, K., Van Elsas, J.D. 1995. Extraction and analysis of 819 microbial DNA from soil, in: van Elsas; J.D.; Trevors, J.T. (Eds.), Nucleic Acids in the 820 Environmenatal: Methods and Applications, Springer-Verlag, Heidelberg, Germany pp. 4982167.

822 Sabree, Z.L., Rondon, M.R., Handelsman J. 2009. Metagenomics. Genetics, Genomics. 622823632.

824 Schloss, P.D., and Handelsman, J. 2005. Metagenomics for studying unculturable 825 microorganisms: cutting the Gordian knot. Genome Biol. 6: 229.

826 Schmidt, M., DeLong, E.F., Pace, N.R. 1991. Analysis of a marine picoplankton community 827 by 16 S rRNA gene cloning and sequencing. J. Bacteriol. 173: 4371-4378.

828 Snaidr, J., Amann, R., Huber, I., Ludwig, W., Schleifer, K.H.1997. Phylogenetic analysis and 829 in situ identyfication of bacteria in activeted sludge. Appl. Environ Microb 63: 2884-2896.

830 Stonehouse B. 1989. Polar Ecology. Blackie. Glasgow \& London, 222pp.

831 Stefanowicz, A. M., Niklińska, M., Laskowski, R. 2009. Pollution-induced tolerance of soil 832 bacterial communities in meadow and forest ecosystems polluted with heavy metals. Eur J 833 Soil Biol. 45: 363-369.

834 Stempniewicz, L. 1990. Biomass of Dovekie excreta in the vicinity of a breeding colony. 835 Colon. Waterbirds 13:62-66.

836 Stempniewicz, L., Zwolicki, A., Iliszko, L., Zmudczynska, K., Wojtun, B. 2006. Impact of 837 plankton- and fish-eating seabird colonies on the Arctic tundra ecosystem - a comparison. 838 Journal of Ornithology 147: 257-258. 
839 Stempniewicz, L., Błachowiak-Samołyk, K., Węsławski, J.M. 2007. Impact of climate change

840 on zooplankton communities, seabird populations and arctic terrestrial ecosystem-A

841 scenario. Microbes Deep Sea Res. Part II: Top. Stud. Oceanogr.54: 2934-2945.

842 Stempniewicz, L., Goc, M., Kidawa, D., Urbański J., Hadwiczak M., Zwolicki A. 2016.

843 Marine birds and mammals foraging in the rapidly deglaciating Arctic fjord - numbers,

844 distribution and habitat preferences. Clim. Change. doi:10.1007/s10584-016-1853-4.

845 Sundset, M.A., Praesteng, K.E., Cann, I.K, Mathiesen, S.D., Mackie, R.I. 2007. Novel rumen

846 bacterial diversity in two geographically separated sub-species of reindeer. Microb. Ecol. 54:

$847 \quad 424-38$.

848 Tyson, G.W., Chapman, J., Hugenholtz, P., Allen, E.E., Ram, R.J., Richardson, P.M,

849 Solovyev, V.V., Rubin, E.M., Rokhsar, D.S., Banfield, J.F. 2004. Community structure and

850 metabolism through reconstruction of microbial genomes from the environment. Nature

$851 \quad 428(6978): 37-43$.

852 Taberlet, P., Camarra, J.J., Griffin, S., Uhres, E., Hanotte, O., Waits, L.P., Dubois-Paganon,

853 C., Burke, T., Bouvet, J. 1997. Noninvasive genetic tracking of the endangered Pyrenean

854 brown bear population. Mol. Ecol. 6: 869-876.

855 Tekere, M., Lötter, A., Olivier, J., Jonker, N., Venter, S. 2011. Metagenomic analysis of

856 bacterial diversity of Siloam hot water spring, Limpopo, South Africa. Afr. J. Biotechnol. 10:

$857 \quad 18005-18012$.

858 Thomas, M., Gilbert, P., Bandel,t H-J., Hofreiter, M., Barnes, I. 2005. Assessing ancient DNA

859 studies. Trends Ecol. Evol. 20 (10), 541-4.

860 Thomas, T., Gilber,t J., Meyer, F. 2012. Metagenomics - a guide from sampling to data

861 analysis. Microb. Inform. Exp. 2: 3. 
862 Thomsen, P.F., and Willerslev, E. 2015. Environmental DNA - An emerging tool in

863 conservation for monitoring past and present biodiversity. Biol. Conserv. 183: 4-18.

864 Tviet, A.T., Urich, T., Frenzel, P., Svenning, M. 2015. Metabolic and trophic interactions

865 modulate methane production by Arctic peat microbiota in response to warming. PNAS.

866 E2507-E2516.

867 Valentini, A., De Bello, F., Chave, J., Thuiller, W., Wincker, P., Cruaud, C., Gavory, F.,

868 Rasmussen, M., Gilbert, M.T., Orlando, L., Brochmann, C., Willerslev, E., Taberlet, P. 2012.

869 DNA from soil mirrors plant taxonomic and growth form diversity. Mol Ecol. 15:3647-55.

870 doi: 10.1111/j.1365-294X.2012.05545.x. Epub 2012 Apr 16.Varin, T., Lovejoy, C., Jungblut,

871 A.D., Vincent, W.F., Corbeil, J. 2012. Metagenomic analysis of stress genes in microbial mat

872 communities from Antarctica and the High Arctic. Appl Environ Microbiol. 78(2):549-59.

873 doi: 10.1128/AEM.06354-11. Epub 2011 Nov 11.

874 Vikhamar-Schuler, D., Hanssen-Bauer, I., Schuler,T.V., Mathiesen, S.D., Lehning M. 2013.

875 Use of a multilayer snow model to assess grazing conditions for reindeer. Ann. Glaciol.

876 54(62) doi:10.3189/2013AoG62A30.

877 Yergeau, E., Hogues, H., Whyte, L.G, Greer, C.W. 2010. The functional potential of high

878 Arctic permafrost revealed by metagenomic sequencing, qPCR and microarray analyses. The

879 ISME Journal, 4:1206-14. doi: 10.1038/ismej.2010.41.

880 Yoccoz, N.G., Bråthen, K.A., Gielly, L., Haile, J., Edwards, M.E., Goslar, T., Von Stedingk,

881 H., Brysting, A.K., Coissac, E., Pompanon, F., Sønstebø, J.H., Miquel, C.,

882 Wainwright, S.C., Haney, J.C., Kerr, C.A., Golovkin, N., Flint, M.V. 1998. Utilization of

883 nitrogen derived from seabird guano by terrestrial and marine plants at St. Paul, Pribilof

884 Islands, Bering Sea, Alaska. Mar. Biol. 131:63-71. 
885 Wemheuer, B., Wemheuer, F., Daniel, R. 2012. RNA-Based Assessment of Diversity and 886 Composition of Active Archaeal Communities in the German Bight. Archaea, doi:

$887 \quad 10.1155 / 2012 / 695826$.

888 Wexler, M., Bond, P.L., Richardson, D.J., Johnston, A.W. 2005. A wide host-range

889 metagenomic library from a waste water treatment plant yield a novel alkohol/aldehyde

890 dehydrogenase. Environ. Microbiol. 7: 1917-1926.

891 Wojciechowska, A., Zwolicki, A., Barcikowska, A., Stempniewicz, L. 2015. The structure of

892 Cochlearia groenlandica population along the bird colony influence gradient (Hornsund,

893 Spitsbergen). Polar Biol. 38, 11: 1919-1930.

894 Willerslev, E., Hansen, A.J., Christensen, B., Steffensen, J.P., Arctander, P. 1999. Diversity of 895 Holocene life forms in fossil glacier ice PNAS 96, 8017-8021, doi: 10.1073/pnas.96.14.8017.

896 Willerslev, E., Cappellini, E., Boomsma, W., Nielsen, R., Hebsgaard, M.B., Brand, T.B.,

897 Hofreiter, M., Bunce, M., Poinar, H.N., Dahl-Jensen, D., Johnsen, S., Steffensen, J.P.,

898 Bennike, O., Schwenninger, J.L., Nathan, R., Armitage, S., de Hoog, C.J., Alfimov, V.,

899 Christl, M., Beer, J., Muscheler, R., Barker, J., Sharp, M., Penkman, K.E., Haile, J., Taberlet,

900 P., Gilbert, M.T., Casoli, A., Campani, E., Collins, M.J. 2007. Ancient biomolecules from

901 deep ice cores reveal a forested southern Greenland. Science. 6;317(5834):111-4.

902 Willerslev, E., Davison, J., Moora, M., Zobel, M., Coissac, E., Edwards, M.E., Lorenzen,

903 E.D., Vestergård, M., Gussarova, G., Haile J., Craine, J., Gielly, L., Boessenkool, S., Epp,

904 L.S., Pearman, P.B., Cheddadi, R., Murray, D., Bråthen, K.A., Yoccoz, N., Binney, H.,

905 Cruaud, C., Wincker, P., Goslar, T., Alsos, I.G., Bellemain, E., Brysting, A.K., Elven, R.,

906 Sønstebø, J.H., Murton, J., Sher, A., Rasmussen, M., Rønn, R., Mourier, T., Cooper, A.,

907 Austin, J., Möller, P., Froese, D., Zazula, G., Pompanon, F., Rioux, D., Niderkorn, V.,

908 Tikhonov, A., Savvinov, G., Roberts, R.G., MacPhee, R., Gilbert, M.T., Kjær, K.H., Orlando, 
909 L., Brochmann, C., Taberlet, P.2014. Fifty thousand years of Arctic vegetation and 910 megafaunal diet. Nature 506:47-51.

911 Valentini, A., Miquel, C., Nawaz, M.A., Bellemain, E., Coissac, E., Pompanon, F., Gielly, L.,

912 Cruaud, C., Nascetti, G., Wincker, P., Swenson, J.E., Taberlet, P. 2009. New perspectives in 913 diet analysis based on DNA barcoding and parallel pyrosequencing: the trnL approach. Mol. 914 Ecol. Resour. 9(1):51-60.

915 Van der Wal, R., and Brooker, R.W. 2004. Mosses mediate grazer impacts on grass 916 abundance in arctic ecosystems. Func. Ecol. 18: 77-86.

917 Varin, T., Lovejoy, C., Jungblut, A.D., Vincent, W.F., Corbeil, J. 2012. Metagenomic 918 analysis of stress genes in microbial mat communities from Antarctica and the High Arctic. 919 Appl Environ Microbiol. 2012 Jan;78(2):549-59. doi: 10.1128/AEM.06354-11. Epub 2011 $920 \quad$ Nov 11.

921 Venter, J.C., Remington, K., Heidelberg, J.F, Halpern, A.L., Rusch, D., Eisen, J.A., Wu, D., 922 Paulsen, I., Nelson, K.E., Nelson, W., Fouts, D.E., Levy, S., Knap, A.H., Lomas, M.W., 923 Nealson, K., White, O., Peterson, J., Hoffman, J., Parsons, R., Baden-Tillson, H., Pfannkoch, 924 C., Rogers, Y.H., Smith, H.O.2004. Environmental genome shotgun sequencing of the 925 Sargasso Sea. Science 304(5667):66-74.

926 Vidal, E, Jouventin, P, Frenot, Y (2003) Contribution of alien and indigenous species to plant927 community assemblages near penguin rookeries at Crozet archipelago. Polar Biol. 26:432928437.

929 Větrovský, T., and Baldrian, P. 2013. The variability of the 16S rRNA gene in bacterial 930 genomes and its consequences for bacterial community analyses. PLoS One. 8 (2):e57923. 931 doi: 10.1371/journal.pone.0057923. Epub 2013 Feb 27. 
932 Zawierucha, K., Zmudczyńska-Skarbek, K., Kaczmarek, Ł, Wojczulanis-Jakubas, K. 2015.

933 The influence of a seabird colony on abundance and species composition of water bears

934 (Tardigrada) in Hornsund (Spitsbergen, Arctic). Polar. Biol. 1-11.

935 Zhang, C., and Bennet, G.N. 2005. Biodegradation of xenobiotics anaerobic bacteria. Appl.

936 Microbiol. Biotechnol. 67: 1600-1618.

937 Zhang, T., Wang, N-F., Liu, H-Y., Zhang, Y-Q., Yu L-Y. 2016. Soil pH is a Key Determinant

938 of Soil Fungal Community Composition in the Ny-Ålesund Region, Svalbard (High Arctic).

939 Front. Microbiol. 7:227. doi: 10.3389/fmicb.2016.00227.

940 Zhou, J., Bruns, M.A., Tiedje, J.M. 1996. DNA Recovery from Soils of Diverse Composition.

941 Appl. Environ. Microb. 316-322.

942 Zielińska, S., Kidawa, D., Stempniewicz, L., Łoś, M., Łoś, J.M. 2016a. New Insights into the

943 Microbiota of the Svalbard Reindeer Rangifer tarandus platyrhynchus. Front. Microbiol. 23

944 7:170. doi: 10.3389/fmicb.2016.00170.

945 Zielińska, S., Kidawa, D., Stempniewicz, L., Łoś, M., Łoś, J.M. 2016b. DNA extracted from

946 faeces as a source of information about endemic reindeer from the High Arctic: detection of

947 Shiga toxin genes and the analysis of reindeer male-specific DNA. Polar Biol. doi:

$948 \quad 10.3389 /$ fmicb.2016.01298.

949 Zielińska, S., Kidawa, D., Stempniewicz, L., Łoś, M., Łoś, J.M. 2016c. The Arctic soil

950 bacterial communities in the vicinity of a little auk colony. Front. Microbiol. 7:1298. DOI

$951 \quad 10.1007 / \mathrm{s} 00300-016-1990-2$.

952 Zmudczyńska, K., Olejniczak, I., Zwolicki, A., Iliszko, L., Convey, P., Stempniewicz, L.

953 2012. Influence of allochtonous nutrients delivered by colonial seabirds on soil collembolan

954 communities on Spitsbergen. Polar Biol. 35(8): 1233-1245. 
955 Zmudczyńska-Skarbek, K., Zwolicki, A., Convey, P., Barcikowski, M., Stempniewicz. L.

956 2015. Is ornithogenic fertilization important for collembolan communities in Arctic terrestrial

957 ecosystems? Polar Res.34: 25629. dx.doi:.org/10.3402/polar.v34.25629.

958 Zwolicki, A., Zmudczyńska-Skarbek, K.M., Iliszko, L, Stempniewicz, L. 2013. Guano

959 deposition and nutrient enrichment in the vicinity of planktivorous and piscivorous seabird

960 colonies in Spitsbergen. Polar Biol. 36 (3): 363-372.

961 Zwolicki, A., Zmudczyńska-Skarbek, K., Richard, P., Stempniewicz, L. 2016. Importance of

962 Marine-Derived Nutrients Supplied by Planktivorous Seabirds to High Arctic Tundra Plant

963 Communities. PLoS ONE 11(5): e0154950. doi:10.1371/journal.pone.0154950.

964 Ernest, H.B., Penedo, M.C.T., May, B.P., Syvanen, M, Boyce, W.M. 2000. Molecular

965 tracking of mountain lions in the Yosemite Valley region in California: genetic analysis using 966 microsatellites and faecal DNA. Mol. Ecol. 9, 433-441.

967

968 Figures

969 Figure 1. Example of an ecological network. Relationships between particular chains based

970 on total DNA (microbial DNA, mtDNA and chromosomal DNA) extracted from soil and 971 faecal samples. 


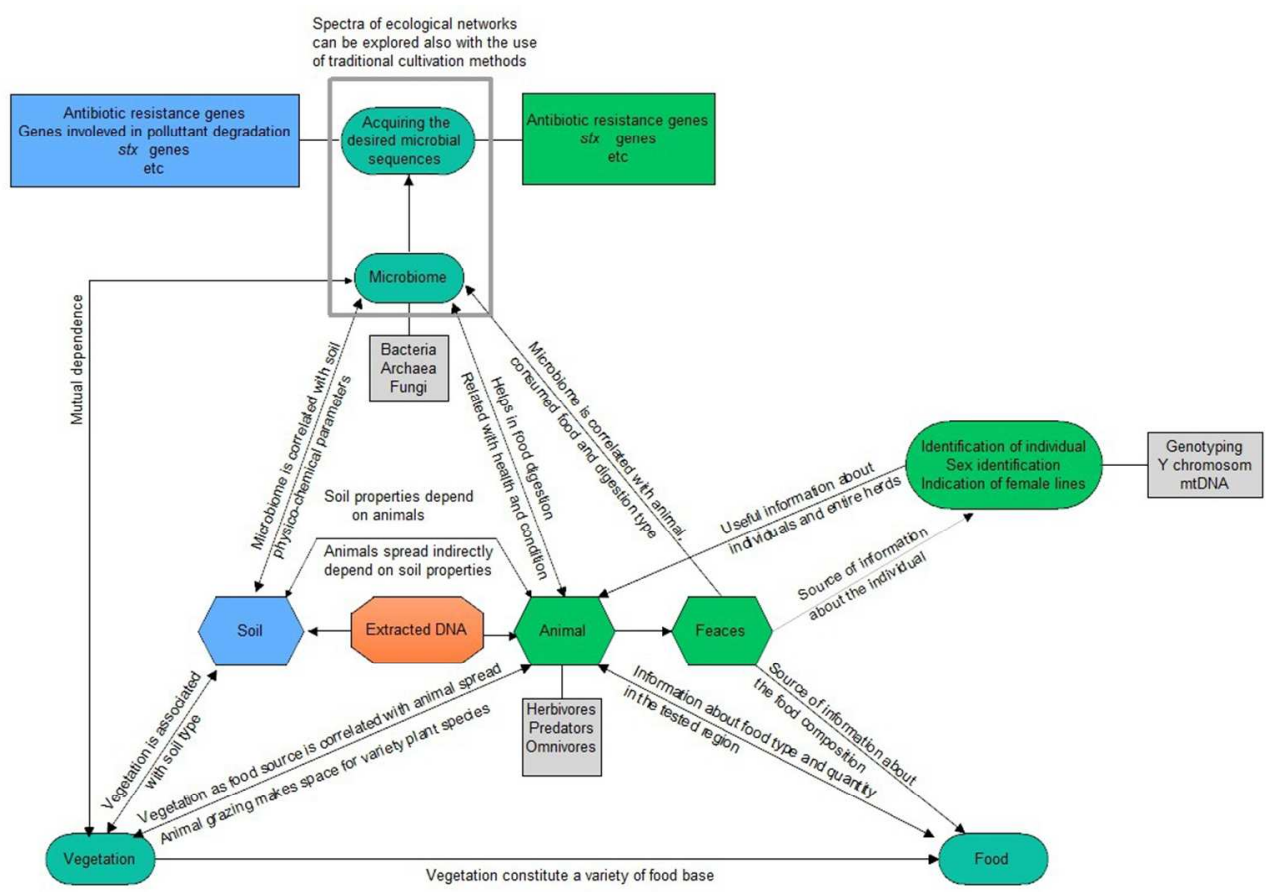

Figure 1. Example of an ecological network. Relationships between particul $396 \times 280 \mathrm{~mm}(72 \times 72 \mathrm{DPI})$ 